\title{
STRATEGIES TO IMPROVE TEACHERS’ SELF-EFFICACY IN INDONESIAN INCLUSIVE ELEMENTARY SCHOOLS \\ A LITERATURE REVIEW
}

\author{
Luluk Shoviana \\ George Mason University - USA
}

\begin{abstract}
Inclusive education (IE) has emerged worldwide since the United Nations held the international campaign of the World Declaration on Education for All. In 2003, the Indonesian government began to promote this new system by a new Law on the National Education System (Act No. 20/ 2003) that directs its regions to have a minimum four inclusive schools. With the IE system, the school attendance of special need students (SNS) increased from 29,I04 to I,500,625. Previous studies suggest that the success of IE implementation depends on teachers. However, the results indicate that Indonesian teachers lack skills and knowledge that lead to their low levels of self-efficacy to support SNS in their classes. Many studies suggest the use of Bandura's sources of self-efficacy theory to provide adequate related professional development programs for teachers. However, they partially discussed strategies to improve teachers' selfefficacy. Thus, the current study aims to synthesize the existing literature on strategies to improve teachers' self-efficacy. Adjustments to Indonesian inclusive education context are discussed.
\end{abstract}

Keywords: Inclusive Education, Self-Efficacy, Elementary School.

ABSTRAK

Pendidikan Inklusif (IE) telah muncul di seluruh dunia sejak Perserikatan Bangsa-Bangsa mengadakan kampanye internasional Deklarasi Dunia tentang Pendidikan untuk semua orang. Pada 2003, pemerintah Indonesia mulai mempromosikan sistem baru ini melalui UndangUndang tentang Sistem Pendidikan Nasional (UU No. 20/2003) yang mengarahkan wilayahnya untuk memiliki minimal empat sekolah inklusif. Dengan sistem IE, kehadiran di sekolah siswa berkebutuhan khusus (SNS) meningkat dari 29.104 menjadi I.500.625. Studi sebelumnya menunjukkan bahwa keberhasilan implementasi IE tergantung pada guru. Namun, hasilnya menunjukkan bahwa guru-guru Indonesia kurang memiliki keterampilan dan pengetahuan yang mengarahpadarendahnyatingkatself-efficacymerekauntukmendukungsiswaberkebutuhankhusus di kelas mereka. Banyak penelitian menyarankan penggunaan sumber teori self-efficacy Bandura untuk menyediakan program pengembangan profesional terkait yang memadai bagi guru. Namun, mereka mendiskusikan sebagian strategi untuk meningkatkan self-efficacy guru. Dengan demikian, penelitian ini bertujuan untuk mensintesis literatur yang ada pada strategi untuk meningkatkan self-efficacy guru. Penyesuaian dengan konteks pendidikan inklusif Indonesia didiskusikan.

Kata kunci: Pendidikan Inklusif, Self-Efficacy, Sekolah Dasar 


\section{A. INTRODUCTION}

Ideally, no one should be discriminated or excluded from the majority of the society. In terms of education practice, inclusive education (IE) seems to be the most righteous vessel of the value of fairness for every student regardless of their special education needs. According to Florian and Black-Hawkins (20II), IE is a concept that promotes opportunities for everybody to get the same classroom experience as the main society. Thus, every student, including those with special education needs, should be able to access any regular school in their neighborhoods without necessarily attending the special need schools which are usually too far to access (Boer, Pijl, Minnaert, 20II). IE has numerous benefits for students and societies. For instance, Special Need Students (SNS) can learn to socialize, and typically developing students can learn tolerance (Boer et al., 20II). In addition, it reduces stigmatization or stereotypes of people with special needs in some societies (Boer et al., 2009; Sharma, \& Nuttal, 2016; Kurniawati, Boer, Minnaert, \& Mangunsong, 2017).

Inclusive education has emerged worldwide since the United Nations held the international campaign of the World Declaration on Education for All (UNESCO, I990). Many countries have followed this emergence through providing a better education for SNS. In 2003, the Indonesian government began to promote this new system by a new Law on National Education System (Act NO. 20/ 2003) that directs its regions to have minimum four inclusive schools (Sheehy, Budiyanto, Kaye, $\&$ Rofiah, 2017). Since then, the number of inclusive schools has been growing. In 2008, the Indonesian Ministry of Education has developed 925 inclusive pioneer schools and now there are more regular schools in Indonesia that are shifting to inclusive schools. This shift provides a solution for the minimum participation of special need students in the Indonesian education system.

According to Hadis (2005), there were only 29,104 from 1,460,333 special need children that could access education. This is because the number of special need schools is very limited and are commonly located only in the regency capital cities. With the inclusive education system, the number of SNS attendance increase to $1,500,625$ from the total of $6,002,500$ children with special education needs in Indonesia (Directorate of Special Education Indonesia, 2017).

Although IE seems very beneficial to be adopted, the success of its implementation depends on teachers. It is because teachers are the ones who will directly implement the IE and deal with students' diverse needs. However, results from previous studies indicate that Indonesian teachers are still lacking skills and knowledge to support SNS in their classes (Sunardi, Yusuf, Gunarhadi, Priyono, \& Yeager, 20II; Kurniawati et al., 20I4). Thus, teachers' hold negative attitudes toward the implementation of the inclusive education system. Teachers' negative attitudes towards inclusive education are associated with lower level of self-efficacy (Boer et al., 20II; Özokcu, 2018; Sheehya, \& Budiyanto, 20I5; Savolainen, Engelbrecht, Nel, \& Malinen, 2012). 
Therefore, Indonesian teachers are considered lacking self-efficacy to provide support for SNS in general classroom setting. However, Indonesian government commits to provide all Indonesian citizens, including those with special needs, with minimum nine years basic education, elementary school education (Kurniawati et al., 2017). As follow up, since 2003, Indonesian government strives to equip teachers with inservice training to support SNS in inclusive settings (Sunardi et al., 20II).

Many studies suggest the use of Bandura's sources of self-efficacy theory to provide adequate related professional development programs for teachers (Sharma \& Nuttal, 20I6; Lorman, Sharma, \& Florin, 2013; Moran \& McMaster, 2009; Chao et al., 2017). They also suggest that teachers' self-efficacy can be the antecedent of the successful implementation of the inclusive education. When teachers believe that they can support SNS in their classrooms, they will most likely to facilitate students' diverse need to be academically successful.

Teachers' efficacy in inclusive education is teachers' beliefs on how they can influence or accommodate various type of students needs and reach the maximum outcomes in teaching (Kerniawati et al., 20I4; Chao et. al, Majoko, 2017). In an effort to improve self-efficacy, Bandura (I977) suggests providing the four sources of self-efficacy: mastery experiences, vicarious experiences, verbal persuasions, physical and emotional states. However, there was no previous study that comprehensively discussed the strategies to provide teachers with the four sources of self-efficacy in teaching SNS. Some studies focus on providing mastery experience and vicarious experience (Block, Taliaferro, Harris \& Krause, 2010; Kurniawati et al., 2017, Sharma \& Nuttal, 2016, Lorman et al., 2013) and few studies focus on providing the four sources of self-efficacy (Ross \& Bruce, 2007; Moran \&McMaster, 2009). Moreover, the fourth source of self-efficacy, physiological and emotional state, is very limited discussed.

Previous studies working on improving teachers' self-efficacy mostly did not address the four sources of efficacy. Indeed, some of them just focus on providing mastery experiences as sources of self-efficacy (Chao et al., 2017; Kosko \& Wilkins, 2009; Peebles \& Mendaglio, 2014; Kurniawati, De Boer, Minnaert, \& Magnusson, 20I4).

A meta-analysis study on intervention to improve teachers' self-efficacy by Ashford, Edmunds, and French (2010) concluded that each self-efficacy sources can strengthen the impact of each other. For instance, the study noted that inducing verbal persuasion while providing vicarious experience can significantly improve self-efficacy. Thus, the current study aims to synthesize the existing literature on strategies to improve teachers' self-efficacy for IE so that they can provide support for students with diverse learning needs. First, the concept of self-efficacy will be explained. Next, strategies from previous studies are synthesized. Then, adjustments to Indonesian inclusive education context are discussed. This study provides the possible strategies to holistically address the four sources of self-efficacy. The results of the 
current study can be used to design a holistic approach to improve teachers' self-efficacy in including SNS in Indonesian elementary school. The implication of the current study can be used by training providers, school management, or other stakeholders.

\section{B. TEACHERS' SELF-EFFICACY IN INCLUSIVE EDUCATION.}

In applying strategies to improve teachers' self-efficacy, it is important to understand the concept of self-efficacy first. Bandura (I977) defines self-efficacy as "beliefs in one's capabilities to organize and execute the courses of actions required to produce given attainments" (p. 3). Teachers' selfefficacy in IE is teachers' beliefs that they can contribute to their students' academic and social outcomes within the inclusive classroom (Boer et al., 2017). Teachers' selfefficacy influence the way they approach challenges, goals, amount of effort they demonstrate, their outcome expectations, and their perseverance when faced with challenges. Teachers' self-efficacy determine what will teachers do with their skills and knowledge (Sharma, \& Nuttal 2016; Ekins, Savolainen, \& Engelbrecht, 2016). According to Bandura (I997), "People's level of motivations, affective states and actions are based more on what they believe than on what is objectively true" (p. 2). For instance, two teachers that have similar skills and knowledge will perform differently due to their different level of self-efficacy.

Teachers with the high level of selfefficacy would be willing to try to include and facilitate SNS in their class while teachers with the low level of self-efficacy will avoid including SNS in their class and prompt the SNS to a special school. Considering the important role of self-efficacy, it is important to understand how this belief is formed. Bandura (I977) suggests that people perceived their self-efficacy based on four primary sources (i.e. mastery experiences, vicarious experiences, verbal persuasions, physiological and emotional states).

With regards to these four primary sources, the first, mastery experiences, refers to people's successful experience in accomplishing one task that is interpreted as the beliefs about their capabilities. Even though mastery experiences are considered as the most influential sources of self-efficacy, they do not determine self-efficacy. Other environmental factors such as modeling, social persuasions, and physiological states also contribute to forming people's selfefficacy (Ekins et al., 2016). Vicarious experiences refer to the observation of others' way to accomplish one task (modeling). This source is beneficial particularly for people who have limited experience or who doubt their abilities on a particular task. Verbal persuasion refers to feedback that people receive from their important others such as colleagues, seniors, or school principles.

Physiological and emotional states refer to responses from the body for certain condition such as sweating, anxiety, and stress. People will be more likely to expect success when they experiencing positive arousal compare to when they anxious about particular tasks. Bandura also suggests clues to provide sources of self-efficacy as described in figure $I$. 


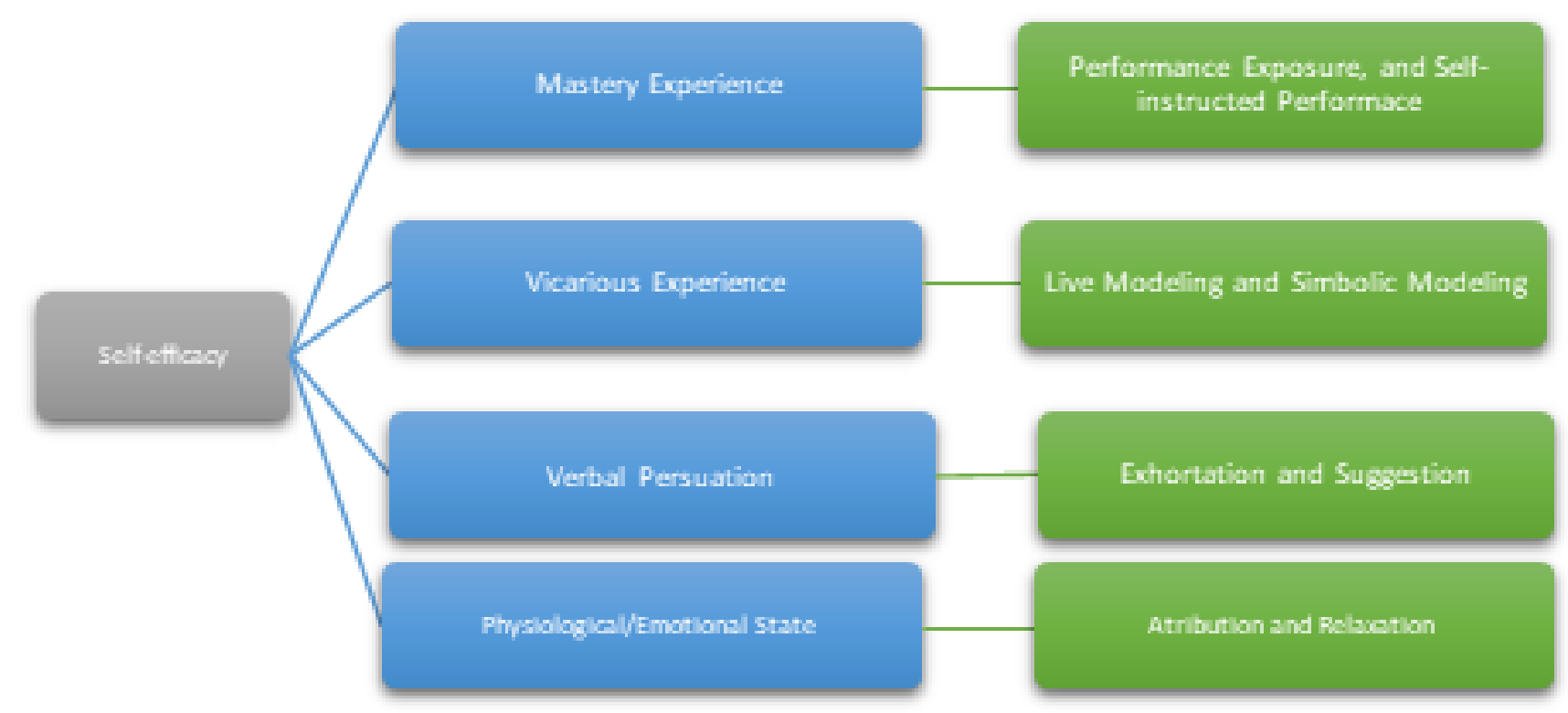

Figure I. Bandura's (I977) sources of self-efficacy theory

\section{STRATEGIES TO PROVIDE SOURCES} OF SELF-EFFICACY FOR TEACHERS

A number of empirical studies evaluate the effectiveness of some strategies to improve teachers' self-efficacy, including mastery experience, vicarious experience, verbal persuasion, and physiological and emotional states.

Mastery experiences. Bandura (1977) suggests that mastery experiences can be approached by providing performance exposure in the expected task as well as selfinstructed performance. Successful trials in accomplishing one task will improve mastery experiences while failing will lower them. Moreover, when the failures happen at the beginning of learning particular tasks, they will significantly lower self-efficacy. However, after strong efficacy has been shaped, future occasional failures with similar tasks will less likely to have negative impacts on selfefficacy. Thus, at the beginning of mastering particular tasks, helping or coaching is important. Help should be appropriate, less controlling and more autonomy support.
The appropriate help is important to maintain personal achievement beliefs. Thus, in future situations where there is no help, people still believe that they can manage to do the similar tasks. To sum up, in providing mastery experiences on particular tasks, it is important that designed interventions provide appropriate guidance or coaching as well as practical activities that are most similar to those in which self-efficacy is expected to improve.

Previous studies suggest several strategies to provide mastery experiences. Ross and Bruce (2007) conducted an experimental study of the effect of a designed professional development on elementary school teachers' self-efficacy in teaching math ( $\mathrm{N}=\mathrm{I06})$. They addressed the mastery experience source by strengthening teachers' competence in inclusive classroom strategies as well as knowledge on students' type of needs. Also, in their professional development, they provided a session for teachers to practice their new competence using case study scenarios. The results show that teachers' self-efficacy 
increases after the professional development. Similarly, Moran and McMaster (2009) investigated the relationship of four professional development formats with teachers' self-efficacy of regular elementary school teachers for reading instruction $(\mathrm{N}$ = 93). Using a quasi-experiment design, they tested four formats of professional development. In targeting the mastery experience, they added one and a half hours of the practice session of each presented strategy. In addition, they also provided 45 minutes of the coaching session with the workshop presenter. The results indicated that their professional development formats effectively improve teachers' self-efficacy beliefs. Findings from these two studies also supported by other similar studies (Forlin, Sharma, \& Loreman, 20I4; Kurniawati, de Boer, Minnaert, \& Mangunsong, 2017).

Vicarious experiences. The second most powerful source of self-efficacy is vicarious experiences, or modeling (Block, Taliaferro, Harris, \& Krause, 2010). Modeling can provide an opportunity to translate behavioral conceptions into actual actions. For instance, teachers might wonder how behavioral management strategies that they have learned are applied in the real situations. Bandura (1977) suggests that vicarious experiences can be provided by exposing individuals with either live or symbolic modeling to teachers. Live modeling can be provided by inviting an experienced teacher to perform teaching strategies in an inclusive class while the other teachers observe. Symbolic modeling can be showing a video that performs strategies to teach in a real inclusive classroom situation. Both types of modeling will persuade teachers that if others can teach in inclusive class, they should be able to as well.

Live modeling can be obtained from experts, experienced teachers, or peers. Ross and Bruce (2007) invited experienced teachers to share their experience. Also, they provided the peer modeling by conducting the debriefing session which requires participants to work in a group so that participants can learn from each other about the presented material before. Similarly, Moran and McMaster (2009) addressed vicarious experiences by including 20 minutes of modeling the strategies being taught in the 3 hours workshop. In addition, they also invited a guest speaker, experienced teacher, who shared her experiences working with SEN students in an inclusive primary school. Teachers were required to write up students' individual education program (IEP) based on study cases in small groups of five or six participants each group.

Symbolic modeling can be provided by presenting the evidence of successful implementations of the strategies being taught. Moran and McMaster (2009) provided videos of teachers who manage to provide support for students with diverse learning needs in the actual classroom situations. Thus, teachers were convinced that strategies that they learn in this professional development are proven effective and beneficial. In addition, other research suggests that a weekly newsletter consisting of articles written by inclusive teachers telling about their experience in teaching in inclusive classes also can be used as a symbolic modeling (Boer et al., 20I I). Other studies 
which provide vicarious experiences for teachers through live and symbolic modeling also confirm its effectiveness in improving teachers' self-efficacy (Kurniawati et al., 2017).

Verbal persuasions. This third source of self-efficacy is the commonly used one because of its ease and availability. Bandura (I977) suggests that verbal persuasions can be implemented by giving suggestions or exhortation. Verbal persuasions can be provided inside the training program or outside the training program. The previous study occupies the training material presenters to frequently provide assurance that teachers will be able to successfully teach SNS in inclusive classrooms (Ross \& Bruce, 2007). In addition, the coaching session also can be used to insert verbal persuasions to the teachers (Moran \& McMaster, 2009). Forlin et al. (20I4) conducted a quasi-experiment to 737 teachers (primary, secondary, and special schools) in Hong Kong and highlights that teachers also need to be familiarized to the local legislation and policies that provide support for the implementation of inclusive education in general schools. Thus, suggestion on how teachers can find help when they need it can be another form of verbal persuasions. By acknowledging the available support for teachers from government, it is expected that teachers will be less concerned about their new role as their schools shift from regular to inclusive schools. Furthermore, increasing teachers' knowledge of legislation and policy was found to be a significant predictor of improved teaching efficacy for inclusive practice (Florin et al., 20I4; Ekins,
Savolainen, \& Engelbrecht, 2016). Inside a training program the training presenter or guest speakers are expected to provide this source of self-efficacy while outside the training context colleagues, school principals, government, and even societies are the ones that are expected to provide teachers with verbal persuasions. In the collectivism culture such as Indonesia, this source matters since Indonesian people highly value validation from others about their capabilities.

Physiological or emotional states. People partially use their physiological arousal to judge their ability on a particular thing. Fear-physiological arousal will lead to fear-provoking thoughts and then to task avoidance. Although gaining the other three sources of self-efficacy will lead to lowering negative autonomic physical arousal, physiological and emotional states can be addressed individually. To address the physical or emotional state, Bandura (I977) suggests the use of attribution retraining as well as relaxation training to lift individual's self-efficacy. Alderman (2008) defines attribution retraining as an effort to change the maladaptive beliefs about a particular thing into the adaptive one. For instance, teachers were encouraged to judge their successful teaching not by students' exam scores but by students' participation as well as students' ability in communicating their ideas (Ross \& Bruce, 2007). Research working on attribution retraining modifies avoidance behavior by manipulating the cognitive labeling of physiological or emotional arousal (Alderman, 2008).

In addition, current research also 
suggests the use of mindfulness training as a way to elevate physical and emotional states (Benn, Akiva, Arel, \& Roeser, 2012; Flook, Goldberg, Pinger, Bonus, \& Davidson, 2013; Gold, Smith, Hopper, Herne, Tansey, \& Hulland, 2009). Gold et al. (2009) suggest that 2.5-hour daily meditation during oneweek training can reduce teachers' anxiety significantly. This also confirms findings from Benn et al. (2012). Similarly, Flook et al. (2013) suggest 2 hours twice per day meditation during weekly basis training is also effective to boost teachers' self-efficacy. To sum up, coaching teachers to be able to train their mind through meditation within 2 hours per day can be used to improve their self-efficacy in dealing with challenging task in teaching practice.

\section{DISCUSSION}

Inclusive education is a huge step for Indonesian society. There are macro-level steps that also should be prepared such as the IE policy, the schools' infrastructures as well as the teachers' preparation. In terms of the teachers' preparation, there are also many things that need to be addressed such as teachers' attitudes, and self-efficacy. The current study contributes to one critical aspect of an effort of the successful implementation of IE which is improving teachers' self-efficacy. Considering Bandura's theory of self-efficacy, the current study suggests strategies to provide the four sources of self-efficacy so that it can be used to design a holistic approach to improve teachers' self-efficacy so that they become better IE facilitators (e.g. teacher training program, professional development, teacher preparation courses).
Providing the mastery experiences for IE can be addressed by giving Indonesian teachers with performance exposure and appropriate help. Performance exposure can be achieved by providing Indonesian teachers with a practice session of IE tasks in the training program. The practice session can also be added to a coaching session to provide appropriate guidance or sources of help for Indonesian teachers. Thus, repeated failure in trying to do IE tasks can be reduced so that it would not lower teachers' level of selfefficacy for inclusive practice. Furthermore, the vicarious experiences can be obtained by providing live or symbolic modeling. A form of live modeling in the teacher training can be a guest speaker that telling their success story in teaching in inclusive schools. Otherwise, it also can be an expert or training speakers that modeling some inclusive classroom strategies that are expected to be learned by Indonesian teachers. In addition, peer modeling, prompt Indonesian teachers to work in a small group for some learning activities, can also become vicarious experiences. As to symbolic modeling, it can be provided by showing video of the evidence for successful integration of SNS in a regular classroom setting. For the follow-up, training providers could also deliver symbolic modeling through distributing weekly materials such as a newsletter consist of successful stories of teachers in inclusive schools or some strategies from the IE experts.

Verbal persuasion can be done by directing the training speakers or an expert in a coaching session to continually provide persuasions for teachers or suggesting coping strategies through making teachers familiar 
with the availability of support. A note for the verbal persuasion is that the providers should be someone that is important or respectable for teachers. Within Indonesian context, verbal persuasion is matter since Indonesian people believe that they are part of others and others are part of them. Thus, validation from others can improve their efficacy. In addition, extortion can be done through leaders of governments continually promote the inclusive society as the goal of each city. Universities can also take part in community service by building awareness on the importance of an inclusive society to both the special need people or the mainstream societies. Thus, when inclusion has become a part of Indonesian society, it will be easier for teachers to expect their successful effort in inclusive practice.

The physiological and emotional state can be adjusted through attribution retraining as well as mindfulness training. In Indonesian context, attribution retraining is also needed in refining the concept of SNS. This is because stigmatization of SNS still exists in Indonesian society. Thus, in the training, the speaker could change teachers' behavioral avoidance on SNS by manipulating teachers' cognitive labeling on SNS. For instance, the speakers could reframe that students' diverse learning needs are part of natural occurrence instead of mythical occurrence. In terms of mindfulness training, it is already applied in Indonesian society through their religious practice. The majority of Indonesian people have their own religious practice (i.e. sholah) similar to the mindfulness training practice (i.e. meditation). Sholah requires its practitioners to focus on one thing in its practice, their relationship with God. Every day, Indonesian people practice sholah five times a day from 5 to 10 minutes each. Thus, Indonesian teachers do not need to be trained on the mindfulness techniques. Instead, the mindfulness training can be done by informing Indonesian teachers of the benefit of the existing practice to alleviate the physiological or emotional states in dealing with challenging tasks.

To sum up, to improve teachers' selfefficacy for IE in Indonesia, all stakeholders need to participate in providing teachers with sources of self-efficacy. Especially, because teachers will be the IE agents that facilitate students' diverse needs. Through the inclusive education practice, hopefully, it can be a starting point to shape a better Indonesian society that provides equal opportunity for everybody regardless of their special needs. Future studies might want to conduct an experimental study to test the effectiveness of the strategies suggested by the current study.

\section{REFERENCES}

Act of the Republic of Indonesia on the National Education System, No. 20 (2003). Ashford, S., Edmunds, J., \& French, D. P. (2010). What is the best way to change self-efficacy to promote lifestyle and recreational physical activity? A systematic review with meta-analysis. British Journal of Health Psychology, I5(2), 265-288. doi:I0.I348/I359I0709X46I752

Bandura, A. (1977). Self-efficacy: Toward a unifying theory of behavioral change. Psychological Review, 84(2), I9I-2I5. 
Benn, R., Akiva, T., Arel, S., \& Roeser, R. W. (2012). Mindfulness training effects for parents and educators of children with special needs. Developmental Psychology, 48(5), I476-I487. doi:I0.I037/a0027537 Block, M., Taliaferro, A., Harris N., \& Krause, J. (2010). Using self-efficacy theory to facilitate inclusion in general physical education. Journal of Physical Education, Recreation \& Dance, 8I(3), 43-46. doi:IO.I 080/07303084.2010.10598448

Boer, A. d., Pijl, S. J., \& Minnaert, A. (20I I). Regular primary schoolteachers' attitudes towards inclusive education: a review of the literature. International Journal of Inclusive Education, I5(3), 33I-353. doi: I0.I080/I3603 I I0903030089

Chao, C. N. G., Sze, W., Chow E., Forlin, C., \& Ho, F. C. (2017). Improving teachers' selfefficacy in applying teaching and learning strategies and classroom management to students with special education needs in Hong Kong. Teaching and Teacher Education, 66, 360-369. http://dx.doi. org/I0.1016/j.tate.2017.05.004

Directorate of Special Education (2009). Department of NationaI Education Inclusive Education: Several implications on schooI management and Counseling activities.

Ekins A., Savolainen H., \& Engelbrecht P. (2016). An analysis of English teachers' selfefficacy in relation to SEN and disability and its implications in a changing SEN policy context. European Journal of Special Needs Education, 3 I(2), 236-249. doi:I0.I080/0 8856257.20I6.I I4I5I0

Flook, L., Goldberg, S. B., Pinger, L., Bonus, K., \& Davidson, R. J. (2013). Mindfulness for teachers: A pilot study to assess effects on stress, burnout, burnout, and teacher efficacy. Mind, Brain, and Education, 7, I82-I95. doi:IO.I I I I/mbe.I2026

Florian, L., \& Black-Hawkins, K. (20II). Exploring inclusive pedagogy. British Educational Reseach Journal, 37(5), 8I3828. https://doi.org/IO.I080/0I4II926 .2010 .501096

Forlin, C., Sharma, U., \& Loreman, T. (20I4). Predictors of improved teaching efficacy following basic training for inclusion in Hong Kong. International Journal of Inclusive Education, I8(7), 718-730. doi:I 0.I080/I3603II6.20I3.8I994I

Gold, E., Smith, A., Hopper, I., Herne, D., Tansey, G., \& Hulland, C. (2010). Mindfulnessbased stress reduction (MBSR) for primary school teachers. Journal of Child and Family Studies, I9(2), I84-I89. doi:I0.I007/ sI0826-009-9344-0

Hadis F. A. (2005). Toward inclusive education in Indonesia a country report [PDF document]. Retrieved from Network for Education Watch Indonesia Online Website: http://new-indonesia.org/beranda/pusatdata/sdgs/487-toward-inclusive-educationin-indonesia-a-country-report.html

Kurniawati, F., De Boer A. A., Minnaert A.E.M.G., \& Magnusson, F. (20I4). Characteristics of primary teacher training programs on inclusion: A literature focus. Educational Research, 56(3), 310-326. doi :I0.I080/00I3I88I.20I4.934555

Kurniawati, F., de Boer, A. A., Minnaert, A. E. M. G., \& Magnusson F. (2017). Evaluating the effect of a teacher training program on the primary teachers' attitudes, knowledge and teaching strategies regarding special educational needs. Educational Psychology, 37(3), 287-297. doi:I0.I080/0I443410.2 
0I6.I I76I25

Kurniawati, F., Minnaert, A., Mangunsong, F., \& Ahmed, W. (2012). Empirical study on primary schools teachers' attitude towards inclusive education in Jakarta, Indonesia. Social and Behavioral Science, 69, I430I436.

Kosko, K.W., \& Wilkins J. L. M. (2009). General educators' in-service training and their selfperceived ability to adapt instruction for students with IEPs. Teacher Training and Inclusion, 33(2), I-IO.

Lai, F. T. T., Li, E. P. Y., Ji, M., Li, Wong, W. W. K., \& Lo, S. K. (2016). What are the inclusive teaching tasks that require the highest selfefficacy? Teaching \& Teacher Education, 59, 338-346. http://dx.doi.org/IO.IOI6/j. tate.2016.07.006

Loreman, T., Sharma, U., \& Forlin, C. (2013). Do pre-service teachers feel ready to teach in inclusive classrooms? A four country study of teaching self-efficacy. Australian Journal of Teacher Education, 38(I). http://dx.doi. org/IO.I422I/ajte.2013v38nI.I0

Moran, M. T., \& McMaster, P. (2009). Sources of self $\square$ efficacy: Four professional development formats and their relationship to self $\square$ efficacy and implementation of a new teaching strategy. The Elementary School Journal, IIO(2), 228-245. doi:I0.I086/60577I

Özokcu, O. (2018). The relationship between teacher attitude and self-efficacy for inclusive practices in Turkey. Journal of Education and Training Studies, 6(3), 6-I2. doi:IO.I I I I4/ jets.v6i3.3034

Palmer, D. H. (2006). Sources of Self-efficacy in a Science Methods Course for Primary Teacher Education Students. Research in Science Education, 36(4), 337-353.
doi:I0.I007/s I I I65-005-9007-0

Peebles J. L., \& Mendaglio S. (20I4). The impact of direct experience on preservice teachers' self-efficacy for teaching in inclusive classrooms. International Journal of Inclusive Education, I8(I2), I32I-I336. doi:I0.I08 0/I3603II6.20I4.899635

Ross, J., \& Bruce, C. (2007) Professional development effects on teacher efficacy: Results of randomized field trial. The Journal of Educational Research, IOI(I), 50-60. doi:I0.3200/JOER.IOI.I.50-60

Savolainen, H., Engelbrecht, P., Nel, M., \& Malinen, O. P. (2012). Understanding teachers' attitudes and self-efficacy in inclusive education: implications for preservice and inservice teacher education. European Journal of Special Needs Education, 27(I), 5I-68. doi:I0.I080/08856257.20I I.6I3603

Sharma, U., \& Nuttal, A. (2016). The impact of training on pre-service teacher attitudes, concerns, and efficacy towards inclusion. Asia-Pacific Journal of Teacher Education, 44(2), I42-I55. doi:IO.I080/I35986 6X.2015.1081672

Sheehya, K., \& Budiyanto. (2015). The pedagogic beliefs of Indonesian teachers in inclusive schools. International Journal of Disability, Development and Education, 62(5), 469485. http://dx.doi.org/IO.I080/I0349I 2X.2015.1061109

Sheehy, K., Budiyanto, Kaye, H., \& Rofiah, K. (2017). Indonesian teachers' epistemological belief and inclusive education. Journal of Intelectual Dissabilities, I-I5. doi:I7446295I77176I3

Sunardi, Yusuf, M., Gunarhadi, Priyono, \& Yeager J. L. (20II). The implementation of inclusive education for students with special needs in Indonesia. Excellence in Higher 
Education, 2(I), I-I0. doi:I0.5I95/ ehe.20II.27

UNESCO (United Nations Education Scientific and Cultural Organization). 1990. The World Declaration on Education for All: UNESCO.

Yada, A., \& Savolainen, H. (2017). Japanese inservice teachers' attitudes toward inclusive education and self-efficacy for inclusive practices. Teaching and Teacher Education, 64, 222-229. https://doi.org/I0.1016/j. tate.2017.02.005 